\title{
OGRODY ISLAMU \\ NA PRZYKŁADZIE ZAŁOŻEŃ OGRODOWYCH ANDALUZJI
}

\author{
Kamila Lucyna Boguszewska \\ Samodzielna Pracownia Architektoniczna, Politechnika Lubelska \\ Independent Architectural Design Studio, The Faculty of Civil Engineering and Architecture \\ e-mail: kamila_boguszewska@interia.eu
}

\begin{abstract}
Streszczenie: Kultura południa Hiszpanii oparta została na zdobyczach cywilizacyjnych chrześcijan, wandalów i imperium muzułmańskiego. Stanowi ona przykład współistnienia różnych kultur i wierzeń. Okres jej największego rozwoju datowany jest na czas panowania kalifa Abd ar-Rahmana i jego następcy Hakma II, jednak najsłynniejsze obiekty, będące najlepiej zachowanymi przykładami architektury i sztuki ogrodowej Islamu, powstały w wieku XIV, kiedy to następował powolny upadek emiratu ze stolicą w Grenadzie. Wówczas wzniesione zostały takie zespoły pałacowo - parkowe jak Alhambra i letni pałac Generalife.

Celem artykułu jest zaprezentowanie najważniejszych osiągnięć arabskiej sztuki ogrodowej południa Hiszpanii. Autorka omawia wybrane założenia ogrodowe Andaluzji opisując ich historię, kompozycję i zastosowaną roślinność ze szczególnym podkreśleniem jej symboliki.
\end{abstract}

Słowa kluczowe: Alhambra, Islam, mudejar, założenie pałacowo - parkowe, ogród

\section{WSTĘP}

Sztuka południowej Hiszpanii stanowi specyficzną mieszkankę wpływów kulturowych. Na tle muzułmańskiego wschodu sztukę Maurów charakteryzuje pewna odmienność. Wynika to z kilku czynników. Jednym z nich był fakt, że tereny obecnej Andaluzji stanowiły w średniowieczu peryferia świata islamskiego. Ważnym czynnikiem były także skomplikowane relacje pomiędzy kalifatami co wpłynęło na pewien rodzaj izolacji, z drugiej zaś strony stało się impulsem do powstania kultury opartej na zdobyczach cywilizacyjnych chrześcijan, wandalów i imperium muzułmańskiego ${ }^{1}$.

\section{HISTORIA}

Południowa część Hiszpanii została zdobyta przez Arabów w roku 711. Początkowo obszar Andaluzji rządzony był przez namiestników kalifów Omajjadzkich. Dopiero pięćdziesiąt pięć lat później na te tereny przybył ostatni potomek rodu Omajjadów, który przejął władzę nad tym terenem, uniezależniając się tym samym od Kalifatu Abbasydzkiego. W roku 929 obszar południowej Hiszpanii staje się kalifatem. Pierwszym kalifem został Abd ar- Rahman i to właśnie za jego panowania oraz późniejszego następcy - Hakama II teren Andaluzji staje się silnym państwem, zaś nauka i kultura osiąga swój największy rozkwit². Rozwijają się nauki ścisłe, teologia, filozofia oraz literatura tzw. poezja andaluzyjska. Za czasów panowania rodu Omajjadów (od wieku XIII zasięg panowania ograniczony do niewielkiego emiratu w pobliżu Grenady) na terenie Andaluzji wznoszone są wówczas najsłynniejsze zespoły pałacowe i sakralne takie jak: meczet w Kordowie (8-9 wiek), miasto - ogród Medina Azahara (X w. ) czy zespół pałacowy w Alhambrze (XIV w.) $)^{3}$ i Generalife datowany na schyłek panowania

1 A. Mez, 1980, Renesans islamu, PIW, Warszawa, s. 20-22.

2 Ibid., s. 20-22.

3 K. Estreicher, 1986, Historia sztuki w zarysie, PWN, Kraków, s. 229. 
Maurów na terenach Hiszpanii. W tym czasie kształtuje się styl mauretański tak zwany mudejar polegający na charakterystycznym detalu architektonicznym: zdobieniach $\mathrm{w}$ formie ornamentu arabeskowego w stiuku, sklepieniach stalaktytowych, różnych inkrustacjach, emaliach czy łukach arabskich. W tym czasie na terenie Andaluzji wzniesiono liczne ogrody adaptując do nowych warunków zdobycze nauki i kultury islamu.

\section{OGRÓD ISLAMU - IDEA}

Ogrody islamu charakteryzują się dużą prostotą planu i symetrią. Najczęściej oparte były na rzucie prostokąta lub kwadratu, często także wydzielone murem z otaczającej przestrzeni. Najczęściej założenia ogrodowe bardzo silnie powiązane były z bryłą budynku któremu towarzyszyły. Czasem stanowiły uzupełnienie, pełniąc rolę zielonych dziedzińców - perskie ogrody - bustan, które później przekształciły się w zielone patia, ozdabiane barwnymi azulejos z kwitnącą roślinnością ustawianą w donicach. Do dzisiaj bowiem tradycja przyozdabiania wewnętrznych dziedzińców ma miejsce w Kadyksie czy Sewilli, gdzie rokrocznie organizowane są konkursy na najciekawiej zaaranżowane zielone wnętrze.

Innym razem tereny ogrodów Islamu uzupełniały całe założenie pałacowe o rozległe przestrzenie czego przykładem są chociażby ogrody Alkazaru w Sewilli czy Alhambry w Grenadzie.

Najbardziej popularny schemat podziału ogrodu, który odnalazł swoje odzwierciedlenie w założeniach ogrodowych Andaluzji to czahar - bah czyli podział ogrodu na cztery kwatery.

Najczęściej podział ten uzyskiwano poprzez budowę dwóch prostopadłych do siebie kanałów $\mathrm{z}$ basenem lub pawilonem usytuowanym w centralnym punkcie, skąd roztaczał się najbardziej atrakcyjny widok na całe założenie ogrodowe. Ogród miał bowiem symbolizować raj opisany w Koranie zaś kanały wodne cztery święte rzeki ${ }^{4}$.

Miał także stanowić miejsce odpoczynku i kontemplacji. Ze względu na wierzenia w jego przestrzeni nie umieszczano rzeźb figuralnych w zamian za to wnętrza zdobione były arabeskami i stiukowymi zdobieniami.

\section{SYSTEMY NAWADNIANIA}

Nieodłącznym elementem ogrodu islamu była woda. W przestrzeń ogrodu wprowadzana była na różne sposoby. Były nimi między innymi systemy kanałów, misy i fontanny sytuowane najczęściej w centralnej części całego założenia. Niedostępność wody i oszczędność w jej użytkowaniu spowodowała bardzo duży rozwój sztuki nawadniana, której mistrzami zostali w Hiszpanii właśnie Maurowie.

Pierwotnie do nawadniania stosowano podziemny system kanałów, przejęty od Persów, tak zwany - qanat, który wykorzystując ukształtowanie terenu, naturalną pochyłość, transportował wodę źródlaną i tę pochodzącą z roztopów do miast. System ten opierał się na szybach, kanałach i zbiornikach. Oprócz systemu nawadniania qanat w ogrodach często stosowano także system śluz, które czasowo były otwierane, a woda, poprzez otwarte kanały tzw. jube, zalewała korzenie roślin.

Nie bez znaczenia był także fakt, że rabaty umieszczane były poniżej poziomu układów komunikacyjnych co znacznie ułatwiało ich nawadnianie ${ }^{5}$. Kanały wodne wykładana były marmurem bądź barwnymi ceramicznymi płytkami tzw. azulejos.

4 A. Mitkowska, M. Siewniak, 1995, Tezaurus sztuki ogrodowej, Oficyna Wydawnicza Rytm, Warszawa, s. 50.

5 P. Hobhouse, 2005, Historia ogrodów, Arkady, Warszawa, s. 24. 


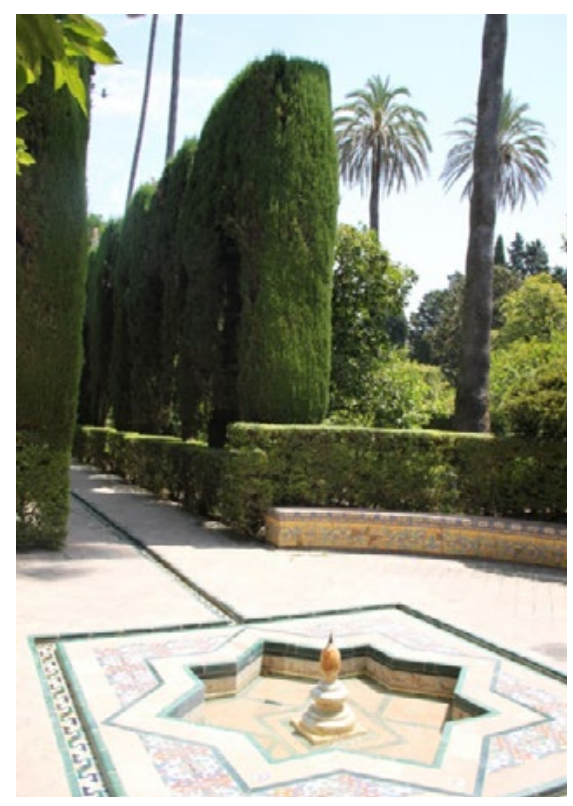

a

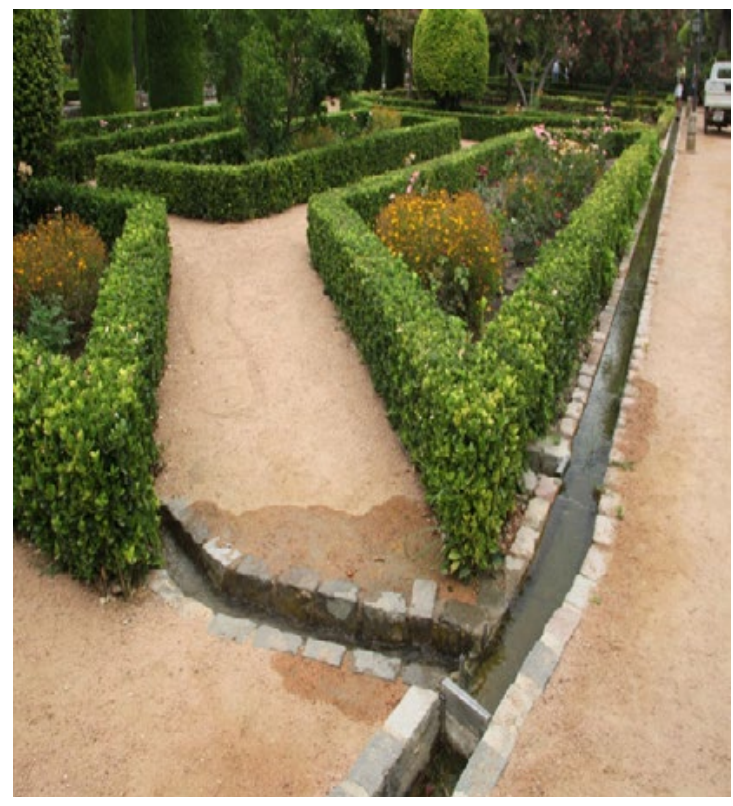

b

Ryc. 1. a - Ogrody Alkazaru, system nawadniania poprzez otwarte kanały, Sewilla, (2015), fot. autor., b - system nawadniający w ogrodzie w Kordobie, Kordoba, (2015), fot. autor

Fig.1. a - Garden of Alcazar, the irrigation system (open channels), Sevilla (2015), photo by author., B - irrigation system in the garden in Cordoba, Cordoba (2015), photo by author

Jednym z najstarszych przykładów ogrodów Islamu na terytorium Europy jest kamienny dziedziniec wysadzany drzewami pomarańczowymi w Kordobie. Usytuowany jest on obok Wielkiego Meczetu, który w XVI wieku został przerobiony na katedrę chrześcijańską. Ogród nosi nazwę Patio de los Naranjos wzniesiony został za czasów Omajjadów. Całość otoczona jest murem. Do ogrodu prowadzi brama zwana Puerta del Perdon usytuowana przy starym minarecie przebudowanym na dzwonnicę ${ }^{6}$. Ogród oparty został na planie prostokąta.

W centralnej części umieszczono fontannę, całość została podzielona na trzy części, które rytmicznie obsadzono drzewkami pomarańczy co ma kontynuować rozmieszczenie kolumn wewnątrz meczetu. Charakterystycznym elementem dziedzińca jest system otwartych kanałów, rozmieszczonych ortogonalnie, doprowadzających wodę bezpośrednio do korzeni drzew pomarańczowych, posadzonych poniżej kamiennej posadzki placu? ${ }^{7}$.

Podobne patio znajduje się przed słynną katedrą wzniesioną na początku XV wieku w Sewilli. Ogród ten poprzedzał niegdyś meczet po którym do dnia dzisiejszego pozostał fragment minaretu przerobiony na wieżę La Giralda.

Dziedziniec posiada plan prostokąta. Płyta placu porozcinana jest systemem kanałów nawadniających. W części centralnej umiejscowiono fontannę na planie koła, która niegdyś była wizygocką chrzcielnicą, służyła ona później muzułmanom do obrządku rytualnych ablucji. Na obrzeżach założenia ustawiono kamienne misy - fontanny wypełnione wodą. Całość obsadzono regularnie drzewkami pomarańczowymi. Ogród podobnie jak ten w Kordobie oddzielony jest od przestrzeni miasta murem.

6 Przewodnik ilustrowany Hiszpania, 2014, Berlitz, s. 204.

7 L. Majdecki, 2007, Historia ogrodów, T.1., PWN, Warszawa, s. 92-93.

8 Przewodnik...(op. cit.), s. 197. 


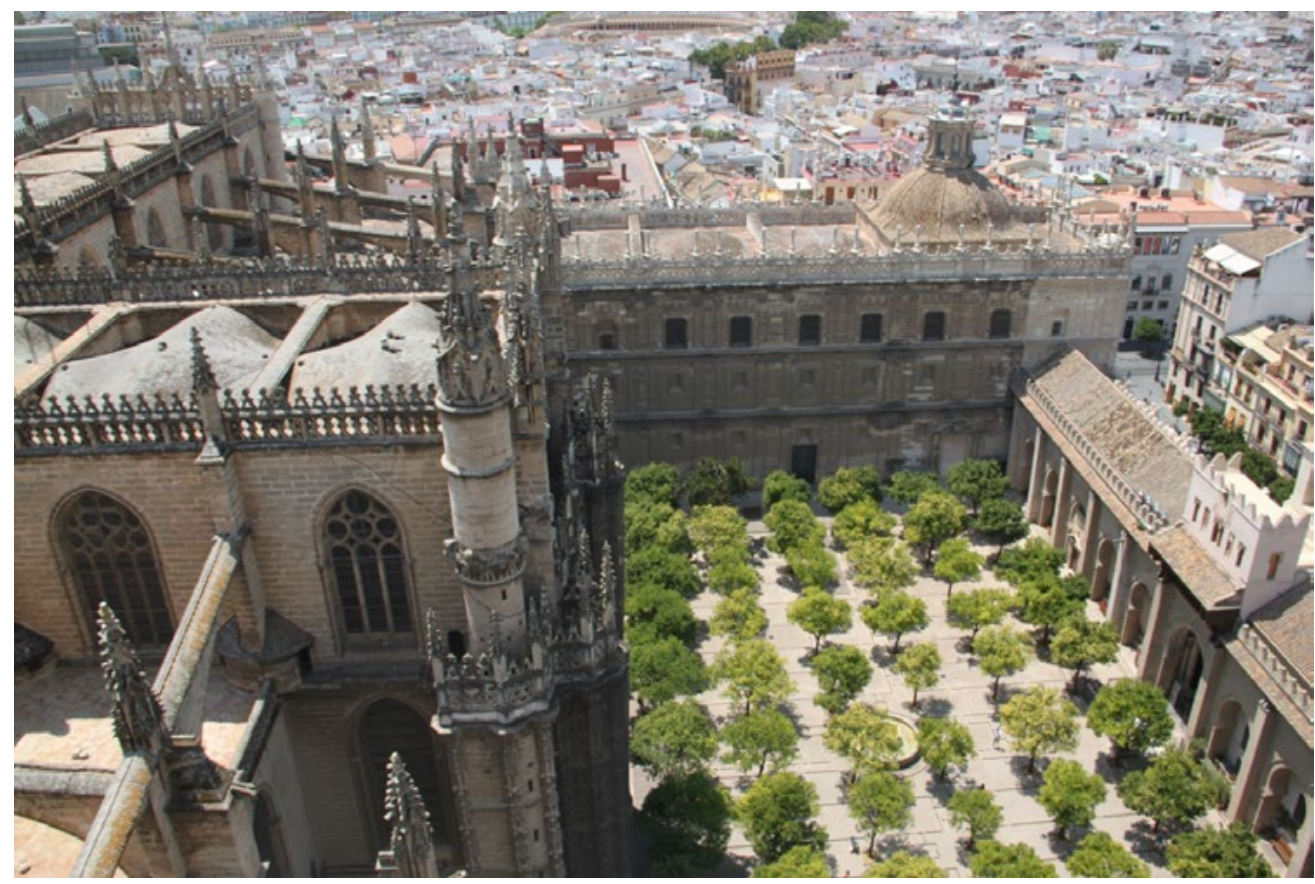

Ryc. 2. Dziedziniec pomarańczy (Patio de los Naranjos), Sewilla, (2015), fot. autor

Fig.2. Courtyard of orange tree, Sevilla, (2015), photo by author

\section{ROŚLINY}

Ogrodu islamu były ogrodami barwnymi i pachnącymi. Miały bowiem obrazować raj opisany w Koranie .To właśnie dzięki zamiłowaniu Maurów do roślin Europa zawdzięcza im takie gatunki jak chociażby drzewa pomarańczowe, cytrynowe czy granatowce.

Rośliny cytrusowe były bowiem znane już w imperium muzułmańskiemu od końca III wieku. Pierwszymi gatunkami uprawianymi i niezwykle rzadkimi były wówczas limona (Citrus limon L.) oraz pomarańcza gorzka (Citrus aurantium L.). Drzewa te zostały sprowadzone z Indii i uprawiane w Umanie, Basrze, Babilioni i Syrii skąd zostały przeniesione do Egiptu i Palestyny9.

Uprawa ekstensywna drzew cytrusowych w Europie nastąpiła w dobie renesansu, kiedy to rośliny introdukowane przez Arabów, stały się bardzo popularne na obszarze południowej Hiszpanii, Włoch oraz Sycylii1 ${ }^{10}$.

W północnej i wschodniej Europie, gdzie klimat był mniej sprzyjający dla tego typu roślin, zaczęto wznosić budynki oranżerii1 ${ }^{11}$ zwane czasem pomarańczarniami ${ }^{12}$. Powstawały także liczne wzorniki opisujące zasady budowy tego typu obiektów.

9 A. Mez, 1980, Renesans... (op. cit.), s. 402.

10 P. Hobhouse, 2005, Historia ... (op. cit.), S. 135.

11 K. Boguszewska, 2013, Oranżerie Województwa lubelskiego w świetle wzorników sztuki ogrodowej z XIX i XX wieku, [w; Annales Universitatis Mariae Curie-Skłodowska, Sectio L Artes, Vol. XI, 1, s. 9-25.

12 Ze względu na temperatury panujące w szklarniach, budynki te dzielone były na tzw. szklarnie zimne określane mianem pomarańczarni, oranżerie - gdzie temperatura w zimie wynosiła 0-5 stopni Celsjusza, cieplarnie 12-15 stopni Celsjusza, szklarnie gorące powyżej 15 stopni Celsjusza. Za: E. Jankowski, 1900, Dzieje Ogrodnictwa w Polsce w zarysie, Warszawa, s. 416. 
W traktatach opisywano także charakterystyczne gatunki roślin, ich wymagania oraz budowę. W Polsce przykładem są książki Edmunda Jankowskiego w których wymienia cytrusy jako rośliny kwieciste zimnej szklarni pod hasłem Citrus figuruje opis cytryn i pomarańczy oraz ich wymagań ${ }^{13}$.

$\mathrm{Na}$ Śląsku znane było natomiast dzieło Johanna van Groena Le Jardinier Hollandois, zaś w traktacie $J$. S. Elsholtza (XVII wiek) opisano zasady wznoszenia cieplarni rozbieranej w lecie. Autor proponuje do ogrodów zimowych takie rośliny jak cytrusy, figi oraz granaty, zaś $\mathrm{z}$ roślin kwitnących róże i jaśminy ${ }^{14}$.

Podobnie rzecz się miała jeśli chodzi o krzew granatowca właściwego (Punica granatum) ${ }^{15}$. Roślina ta, uważana za roślinę biblijną, występowała powszechnie na terenach Ziemi Świętej, później rozprzestrzeniła się na obszary obecnej Tunezji i Egiptu. Do Europy granatowiec został sprowadzony około roku 700 roku. Stało się to za sprawą Arabów. Popularność tej rośliny na Półwyspie Iberyjskim była bardzo duża. W X wieku Maurowie założyli miasto Grenada nazywając je na jej cześć. Owoc granatu do dnia dzisiejszego obecny jest w herbie miasta ${ }^{16}$.

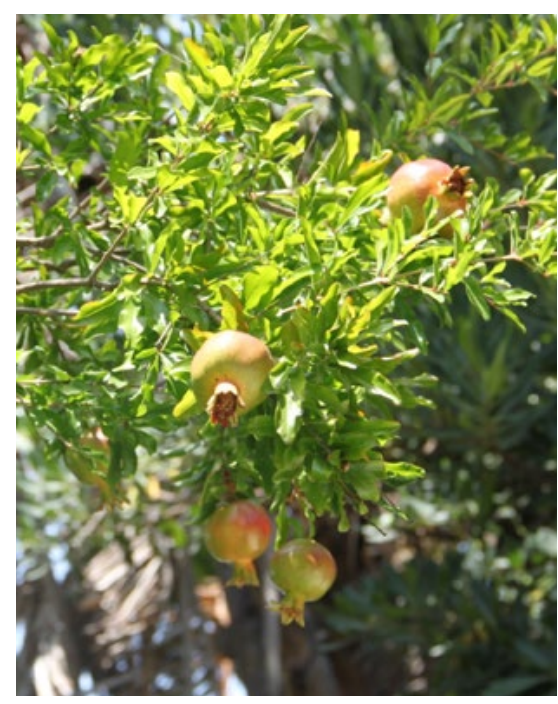

a

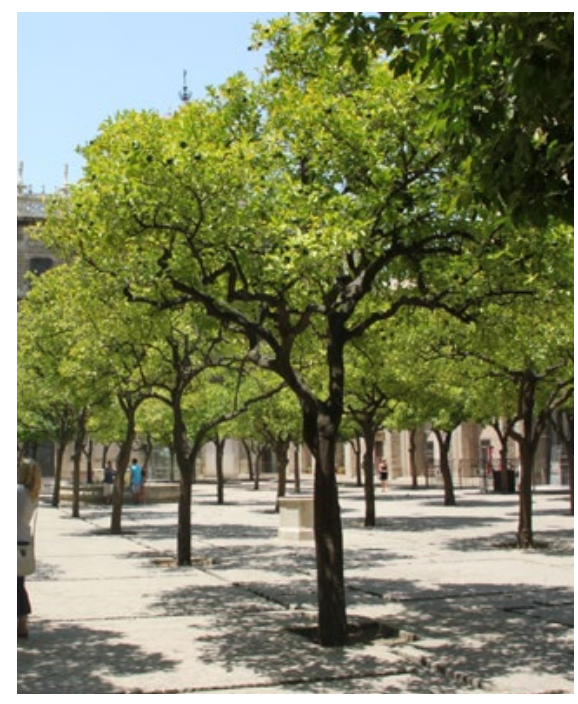

b

Ryc. 3. a - Drzewo Granatowca (Punica granatum), Grenada, (2015), fot. autor., b-drzewo pomarańczowe (Citrus aurantium), Sewilla, (2015), fot. autor

Fig.3. a - Pomegranate tree (Punica granatum), Grenada, (2015), photo by author, $\mathrm{b}$ - Orange tree (Citrus aurantium), Sevilla, (2015), photo by author

Arabom Europa zawdzięcza także pierwsze uprawy nieznanych do tej pory roślin takich jak: daktyli, bawełny, bananów, a także sprowadzenie takich drzew jak cedry, brzoskwinie czy morele ${ }^{17}$.

13 E. Jankowski, 1908, Dla Ogrodników, Warszawa, s. 240-241.

14 M. Jagiełło, W. Brzezowski, 2014, Ogrody na Śląsk, Tom I od średniowiecza do XVII wieku, Oficyna Wydawnicza Politechniki Wrocławskiej, Wrocław, S. 27-30.

15 Podstawą słowotwórczą dla nazwy granat jest łacińskie słowo granum oznaczające ziarno. W Biblii roślinę jak i owoc granatu określano słowem rimmon, zaś w języku arabskim rumman. Za: Z. Włodarczyk, 2008, Siedem upraw biblijnych i ich symbolika, Wydawnictwo Salwator, Kraków, s. 111.

16 W. Kawollek, H. Falk, 2010, Podróż po biblijnych ogrodach, Elipsa, Poznań, s. 25-27.

17 A. Mitkowska, M. Siewniak, 1995, Tezaurus... (op. cit.), s. 24. 
Oprócz roślin cytrusowych, w ogrodach Europy zaczęły pojawiać się także różnego rodzaju rośliny kwitnące, zwłaszcza cebulowe, między innymi: tulipany, szachownice i hiacynty.

Warto także podkreślić, że w ogrodach islamu rośliny posiadały znaczenie symboliczne. Ich rozmieszczenie nie było przypadkowe. Zalecane było sadzenie cyprysów w narożach ogrodu. Aleje główne były obsadzane drzewami dającymi cień takimi jak sosny i cedry. Miejsca nasłonecznione były przeznaczone dla drzew cytrynowych i wawrzynów szlachetnych zaś elementom wodnym ogrodu towarzyszyły krzewy granatowca ${ }^{18}$, symbolizujące powodzenie i płodność. W przeciwieństwie do krzewów granatowca cyprysy były określane mianem drzew śmierci. Na tkaninach często przedstawiano je razem z krzewami kwitnącego migdałowca symbolizującego odrodzenie ${ }^{19}$.

\section{ALHAMBRA I GENERALIFE}

Zespół zamkowy w Alhambrze wraz z pałacem letniem Generalife, tarasowymi ogrodami oraz wzgórzem Albayzin figuruje obecnie na Światowej Liście Dziedzictwa UNESCO. Do dnia dzisiejszego zespół ten (w większości rekonstruowany) stanowi świadectwo kunsztu stylu mudejar.

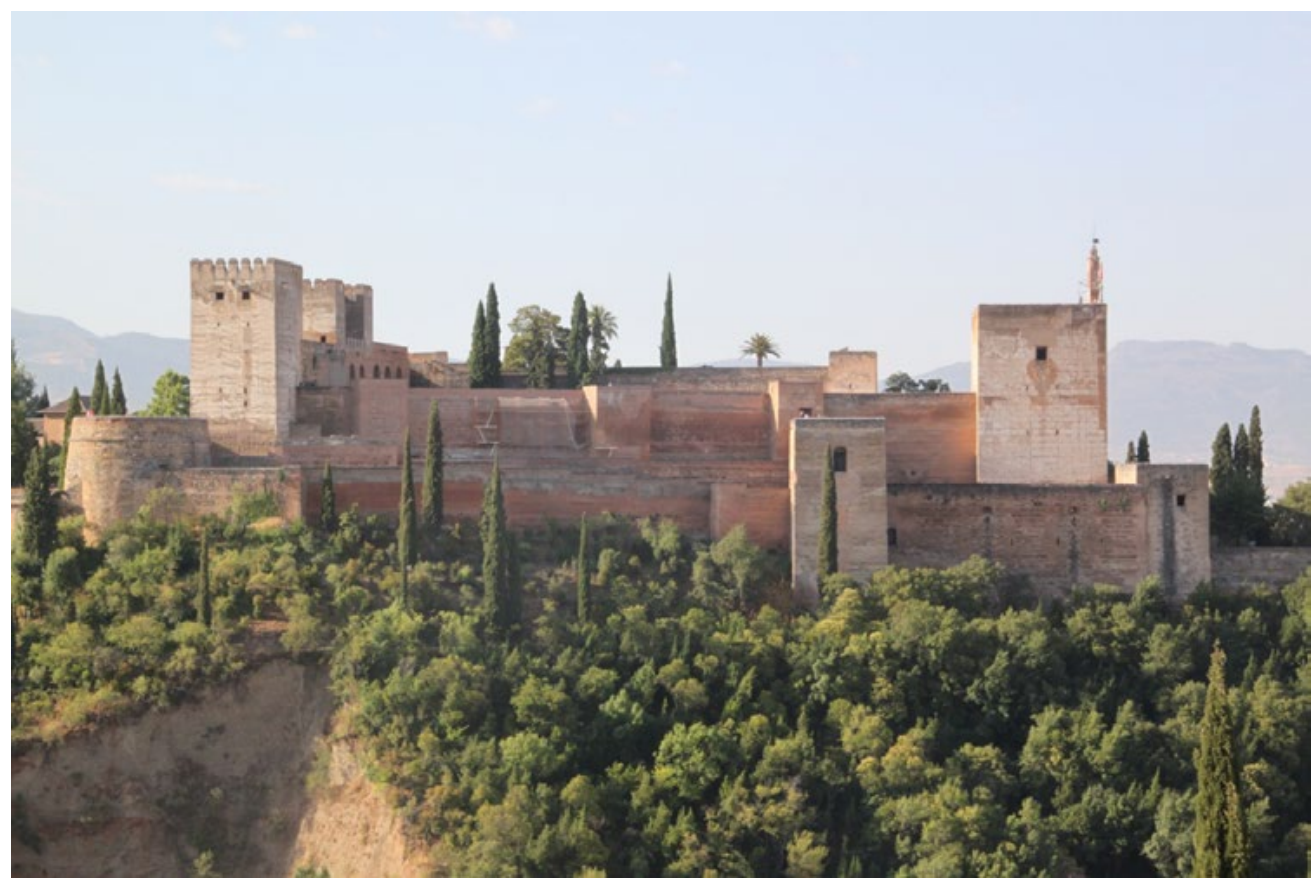

Ryc. 4. Widok na Alhambrę, Grenada, (2015), fot. autor

Fig.4. View of the Alhambra, Grenada, (2015), photo by author

Pałac w Alhambrze datowany jest na wiek XIV i powstał za panowania Muhhamada V. Rozczłonkowana bryła budynku została zaprojektowana wokół dwóch prostopadłych do siebie dziedzińców: Dziedzińca Mirtów (Patio de los Arrayanes) oraz Dziedzińca Lwów (Patio

18 P. Hobhouse, 2005, Historia ... ( op. cit.), s. 69.

19 Ibid., s. 61. 
de los Leones) oprócz nich na terenie pałacu znajdują się jeszcze dwa mniejsze patia Patio de Deraxa i Patio De La Reja ${ }^{20}$.

Jednym z najciekawszych dziedziców na terenie pałacu Nasrydów jest tak zwany Dziedziniec Lwów. Patio posiada plan zbliżony do prostokąta. W centralnej części umieszczona jest okrągła fontanna wsparta na posągach dwunastu marmurowych lwów. Co ciekawe istnieją przypuszczenia, że antyczne rzeźby zostały wykonane przez chrześcijan. Od fontanny odchodzą ortogonalnie cztery kanały dzielące dziedziniec na cztery części. Posadzka wyłożona jest białymi marmurowymi płytami. Zieleń ograniczona została do minimum. Jedynie w narożach dziedzińca rosną niewielkie drzewka pomarańczowe. Patio otaczają z czterech stron arkadowe dziedzińce o charakterystycznych mauretańskich łukach i stiukowych zdobieniach w stylu mudejar.

Prostopadle do dziedzińca Lwów usytuowany jest Dziedziniec Mirtów. Patio oparte jest na planie prostokąta. Większą część zajmuje prostokątny basen z którego dwóch stron usytuowane są wodotryski. Basen graniczy z dwóch stron z żywopłotami z mirtu (Myrtus communis). Stan obecny jest rekonstrukcją $\mathrm{z}$ wieku XIX, kiedy to ponownie wprowadzono nasadzenia roślinne ${ }^{21}$.

Mirt jest wiecznozielonym krzewem kwitnącym na biało. Już w czasach biblijnych stosowany był jako roślina przyprawowa. Na Półwyspie Iberyjskim uprawiany jest jako roślina gruntowa, często stosowana na żywopłoty. Roślina ta jest symbolem czystości. Według wierzeń arabskich miała pochodzić z raju. Mirt symbolizował także nadzieję ${ }^{22}$.

Dziedziniec Mirtów otoczony jest $\mathrm{z}$ dwóch stron arkadowymi podcieniami od północy usytuowana jest wieża zwana Salą Ambasadorów.

Dziedzińce Patio de Deraxa i Patio De La Reja posiadają znacznie mniejsze powierzchnie ich plany zbliżone są do czworokąta. Patio de Deraxa posiada centralnie usytuowana fontannę. Dziedziniec obsadzony jest bukszpanowymi (Buxus sempervirens) parterami wypełnionymi kwitnącymi Agapantami (Agapantus africanus), kłączową rośliną o fioletowych kwiatach zwaną czasem lilią afrykańską. Na obrzeżach posadzono drzewa pomarańczowe (Citrus media) bliżej zaś fontanny usytuowano cyprysy (Cupressus L.). Dziedziniec zamknięty jest $\mathrm{z}$ dwóch stron arkadami.

Pałac Generalife funkcjonował jako rezydencja letnia Ismaila I. Całe założenie oparte jest na systemie tarasowych dziedzińców, które są elementem komplementarnym do architektury pałacu, organizując całość.

Jednym z najsłynniejszych ogrodów pałacu letniego jest Patio de la Acequia, którego centralnym elementem jest długi kanał wodny umieszczony pomiędzy systemem wodotrysków tak zwana aleja wodna ${ }^{23}$. Ogród wydzielony jest z trzech stron murami. Czwartą ścianę stanowi arkadowy mur otwierający się na otaczający krajobraz. W chwili obecnej dziedziniec obsadzony jest różnego rodzaju roślinnością miedzy innymi: bugenwillą (Bougainvillea spectabilis), drzewami pomarańczowymi, mirtami, a z roślin dwuletnich ślazem (Malva L.).

20 L. Majdecki, 2010, Historia...(op. cit.), s. 65.

21 P. Hobhouse, 2005, Historia...(op.cit), s. 71.

22 W. Kawollek, H. Falk, 2010, Podróż... (op. cit.), s. 47.

23 A. Mitkowska, M. Siewniak, 1995, Tezaurus... (op. cit.), s.17. 


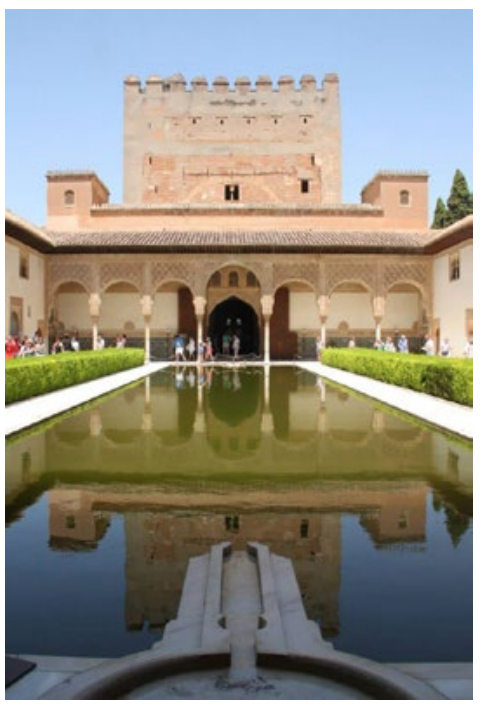

a

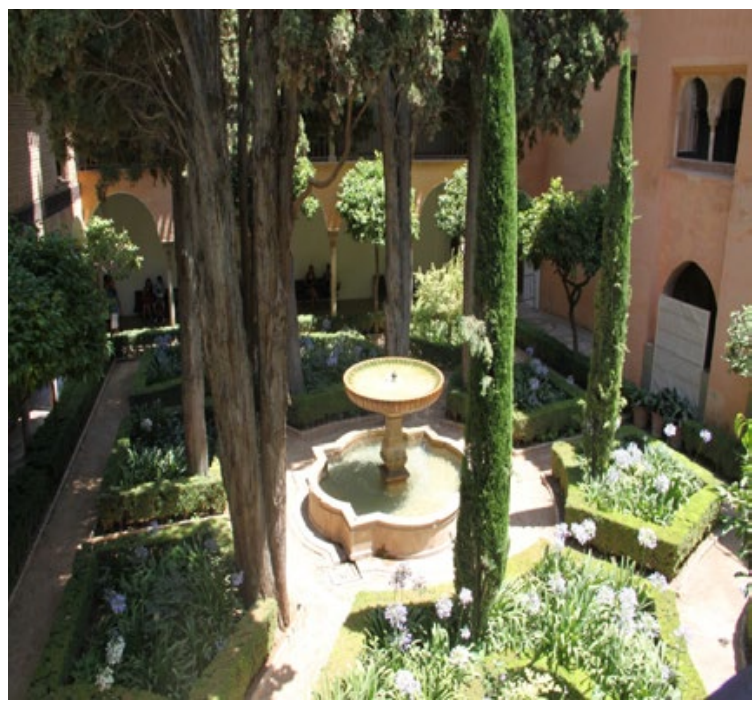

Ryc. 5. a - Dziedziniec Mirtów, Alhambra, (2015), fot. autor., b - Patio de de Deraxa, Alhambra, (2015), fot. autor Fig. 5. a - Courtyard of the myrtles, Alhambra ( 2015), photo by author, b - Patio de Deraxa, Alhambra, (2015), photo by author

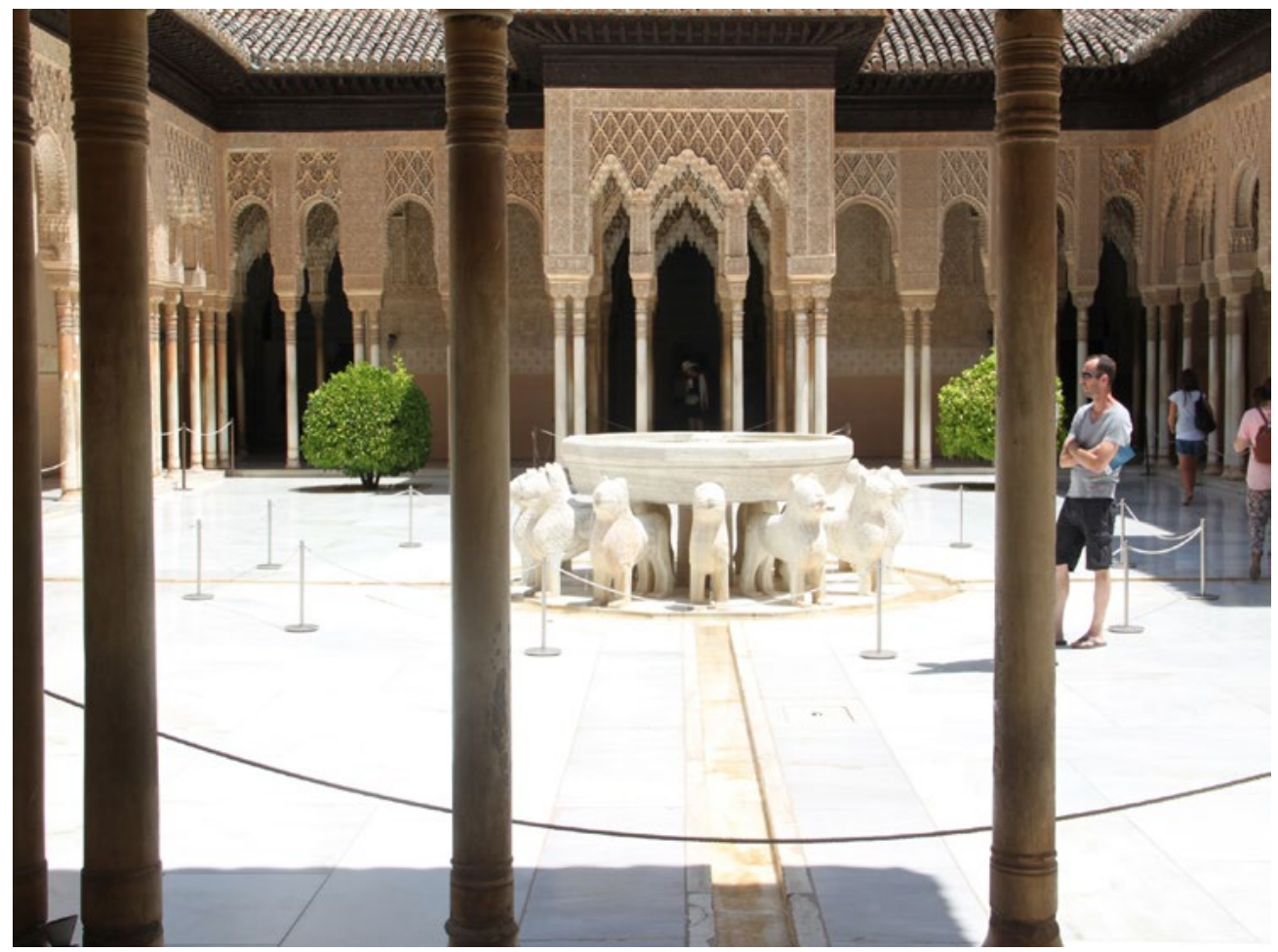

Ryc. 6. Dziedziniec lwów, Alhambra, (2015), fot. autor

Fig. 6. Courtyard of leons, Alhambra, (2015), photo by author 


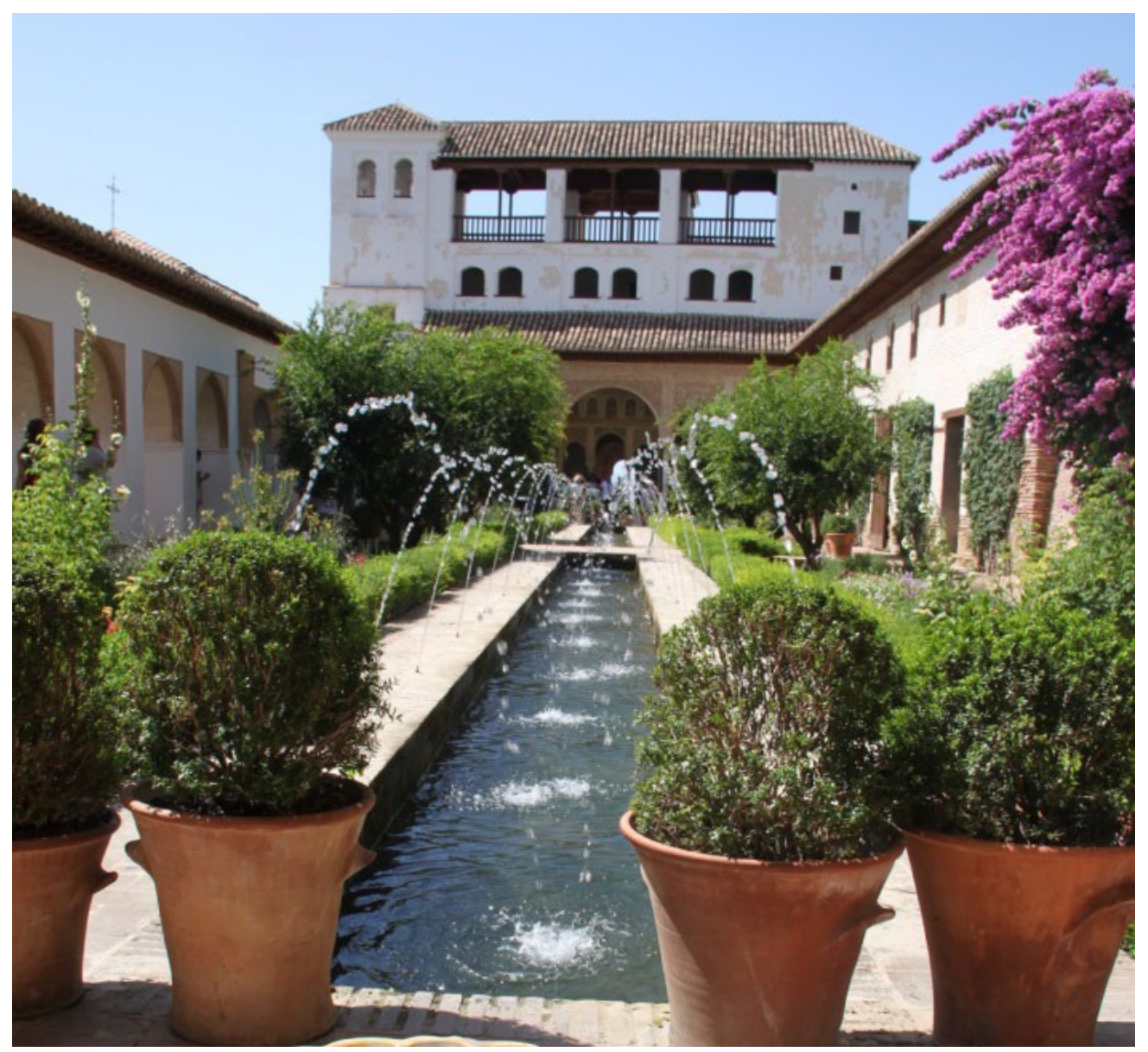

Ryc. 7. Patio de la Acequia, Alhambra, (2015), fot. autor Fig. 7. Patio de la Acequia, Alhambra, (2015), photo by author

\section{PODSUMOWANIE}

Ogrody Andaluzji należą do najstarszych zachowanych ogrodów średniowiecza europejskiego. Wpisane na listę UNESCO stanowią dziedzictwo wielokulturowej Europy. Są także przykładem i wynikiem współistnienia różnych religii i mądrego przetwarzania i adaptowania wzorców i schematów do otoczenia.

Izolacja kalifatu na Półwyspie Iberyjskim zlokalizowanego na peryferiach: imperium muzutmańskiego $\mathrm{w}$ okresie średniowiecza doprowadziła do wykształcenia oryginalnej sztuki tego rejonu (barwne - Azulejos) i stylu mudejar. Postęp myśli technologicznej - systemy irygacyjne, wprowadzenie nowych gatunków roślin do Europy to wszystko zawdzięczamy muzułmańskim mieszkańcom Andaluzji.

Proste, geometryczne plany ogrodów z charakterystycznymi kanałami wodnymi wpisały się na stałe w historię sztuki ogrodowej, stanowiąc świadectw historii tego rejonu.

Sztuka zakładania zielonych dziedzińców - patio wpisało się na stałe w krajobraz miejski Andaluzji. Kadyks, Sewilla należą bowiem do miast słynących i kultywujących tradycję aranżowania przestrzeni wewnątrz domu, tworząc barwne ogrody, konkurujące o miano tego najciekawszego i najlepiej zaaranżowanego. 


\section{PIŚMIENNICTWO}

Boguszewska K., 2013, Oranżerie województwa lubelskiego w świetle wzorników sztuki ogrodowej z XIX i XX wieku, [w:] Annales Universitatis Mariae Curie-Skłodowska, Sectio L Artes, Vol. XI, 1.

Estreicher K., 1986, Historia sztuki w zarysie, PWN, Kraków.

Hobhouse P., 2005, Historia ogrodów, Arkady, Warszawa.

Jagiełło M., Brzezowski W., 2014, Ogrody na Śląsku, Tom I od średniowiecza do XVII wieku, Oficyna Wydawnicza Politechniki Wrocławskiej, Wrocław.

Jankowski E., 1908, Dla Ogrodników, Warszawa.

Jankowski E., 1900, Dzieje Ogrodnictwa w Polsce w zarysie, Warszawa.

Kawollek W., Falk H., 2010, Podróż po biblijnych ogrodach, Elipsa, Poznań.

Włodarczyk Z., 2008, Siedem upraw biblijnych i ich symbolika, Wydawnictwo Salwator, Kraków.

Majdecki L., 2007, Historia ogrodów, T. 1., PWN, Warszawa.

Mez A., 1980, Renesans islamu, PIW, Warszawa.

Mitkowska A., Siewniak M.,1995, Tezaurus sztuki ogrodowej, Oficyna Wydawnicza Rytm, Warszawa.

Przewodnik ilustrowany Hiszpania, 2014, Berlitz.

\section{GARDENS OF ISLAM \\ ON THE EXAMPLE OF GARDEN ASSUMPTIONS IN ANDALUSIA}

Summary: Culture of southern Spain was based on the achievements of Christians, Vandals and the Muslim empire civilization. It is an example of coexistence of different cultures and beliefs. The period of its greatest development dates back to the time of the reign of Caliph Abd al-Rahman and his successor Hakma II, but the most famous objects, which are the best preserved examples of architecture and garden art of Islam, originated in the fourteenth century, when it was followed by a slow decline of the emirate, with its capital in Granada. Then the bands were erected palace - parks as the summer palace of the Alhambra and the Generalife. The aim of the article is to present the most important achievements of Arab art of gardening in southern Spain. The author discusses the chosen garden assumptions Andalusia, describing their history, composition and vegetation followed with particular emphasis on its symbolism.

Keywords: Alhambra, Islam, mudejar, residential complex, garden 